\title{
A Methodological and Evaluation Proposal for Teaching Information Systems in COVID-19 Pandemic
}

\author{
Beatriz Forés Julián \\ Universitat Jaume I
}

\author{
Alba Puig Denia \\ Universitat Jaume I \\ José María Fernández Yáñez \\ Universitat Jaume I
}

\begin{abstract}
The global outbreak of the COVID-19 pandemic has heightened attention to e-learning based education models. In this regard, this study reports the methodology and evaluation for teaching a subject related to information systems at higher education. The proposal raised in this document is supported by the students' anonymous assessment through an online survey. The results of the research revealed that even that students have a positive attitude towards e-learning, a vast majority of them still have a predilection for face-to-face learning. Additionally, the main advantages, difficulties to follow online learning, as well as suggestions of students for improving the learning process are exposed. Based on these findings, research implications for universities and researchers are discussed.
\end{abstract}

Keywords: e-learning, online platform and resources, higher education, information systems, COVID, students' assessment

\section{INTRODUCTION}

Since the World Health Organization declared the outbreak of coronavirus (COVID-19) disease a pandemic in March 2020, containing the spread of the virus has been an international priority (Huang et al., 2020). To reduce community transmission of the disease, many countries adopted unprecedented restrictions to isolate the population in their homes avoiding social contact.

COVID-19 pandemic has prompted far-reaching changes in the teaching process in universities to adequately address the educational needs of students in this period of health crisis. Although we are not in the previous state of alarm, the forecasts of group immunization through vaccination campaigns are still uncertain. In this vein, the main strategies available to prevent rapid spread of infections are related to social distancing. In this context, educational models based on online learning (e-learning) seems to be the most plausible alternative.

Therefore, many higher education institutions, in order to comply with health regulations but to guarantee the continuity of the educational process, have adopted online or e-learning (Ali, 2020). 
Traditionally, e-learning has been considered as an option or a complement to traditional face-to-face learning. However, the spread of the virus has provoked a change of paradigm regarding the modes of learning. During the period of home confinement, internet-based learning has become an indispensable element to maintain the activity of higher education institutions, but also for the rest of the educational levels.

Previous studies (e.g. Adnan \& Anwar, 2020; Dhawan, 2020) suggest that e-learning models offer many advantages both for students and lectures. In this sense, online learning is considered more flexible because it removes the barriers of time and it can be tailored to the students' needs (Coman et al., 2020). Information technologies provide students with tools such as e-mail, forums, or video conference systems to advance their learning and improve the communication both between students and among the lecturers and the students (Suresh et al., 2018). Moreover, professors can also take advantage of technologies to carry out some tasks, for instance, control of the contents, time control of the assignments, or adapt the syllabus as the situation requires (Suresh et al., 2018).

However, the use of online learning models is not free of obstacles that can hinder their proper development and also limit students' learning. Lecturers' lack of experience in online teaching or students feeling of isolation are just a few examples (Coman et al., 2020). Specifically, the OECD stresses the importance of maintaining adequate teaching loads, providing support to students throughout the process and taking into account any limitations in student accessing internet or electronic devices (OECD, 2020). Therefore, lecturers, and the universities, in general terms, have to give the best of themselves so that the pandemic does not stop learning processes, dealing at the same time with the challenges that online learning represents.

Thus, considering all changes introduced in the learning process, we believe that it is essential to examine whether students have adapted to e-learning in this pandemic situation, whether they are satisfied with their learning and assimilation of contents and what are the problems they have faced. The results obtained would help us to improve the e-learning process, by providing useful information on the methods and resources used in a specific subject linked to Information Management Systems.

\section{THE SUBJECT: INTRODUCTION TO FIRM INFORMATION SYSTEMS}

The subject Introduction to Firms Information Systems is taught in the degrees of Business Administration, Finance and Accounting, and Economics at the Universitat Jaume I. This subject of 6 credits is compulsory in the first year of those degrees (the three degrees share subjects during the first two years); it is the first contact of students with information systems in organizations. The importance of Information and Communication Technologies (ICT) and Information Systems (IS) for different aspects in business competitiveness has made mastering technology a key aptitude to work in almost any organization. In this sense, and according to the Randstad Professionals employment company, many organizations are looking for a professional profile that combine technological skills with strategic and business skills. This specific subject aims to: 1) increase students' knowledge about the use and application of information systems and, more specifically, Enterprise Resource Planning (ERP), for strategic decisions, for the relationships with the main stakeholders in this decision making and for the operational efficiency; 2) raise awareness about the importance of information systems training for professional success; and 3) educate from a focus of sustainability and action for transformation, through a more practical and professional vision of the subject. In addition, in the academic year 2018/2019, this subject became part of the International Degree Seal Program of the Universitat Jaume I, approved in the Governing Council on March 20, 2018.

Specifically, the subject is divided into three main parts: theoretical foundations, aimed to explain the main concepts of the subject through participatory master classes and to introduce and solve some business cases; laboratories, where students should solve case problems by using the Microsoft Excel program; and final project, where students work in groups of 4-6 people, assuming the role of junior consultants, to develop a database project through which an organization can manage all its information. 


\section{THE METHODOLOGICAL AND EVALUATION ADAPTATION TO COVID-19 CONTEXT}

Quick developments in technology have made distance education easy (Dhawan, 2020). The information technologies and e-learning systems are seen as essential factors in carrying out the activity of universities (Forés et al., 2019). E- learning could be defined as learning experiences in synchronous or asynchronous environments using different devices (e.g., mobile phones, laptops, etc.) with internet access. In these environments, students can be anywhere (independent) to learn and interact with instructors and other students.

Institutions and organizations should use these technological advancements to prepare contingency plans to deal with challenges such as pandemics and natural disasters (Dhawan, 2020). In this vein, higher education institutions have to invest more and more in providing online systems and devices and integrating them both in teaching and learning processes. This supportive effort implies reinforcing lecturers' formation in using this software introduced in managing lectures and monitoring and evaluating students (Forés et al., 2019). In this regard, universities should develop training sessions for lecturers to stimulate their own performance and the quality of the educational process.

\section{Best Practices for Organizing the New Learning Context}

Most controversies in higher education during COVID-19 pandemic about e-learning usage have been focused on how the instructors integrate new technology in the learning process to satisfy the students' needs.

Universities such as Universitat Jaume I have made a great effort in investing in new devices and tools for students to follow-up online classes, and in creating specific programs to solve students' technical problems with internet connectivity. In addition, and in order to optimize e-learning process and properly face the Coronavirus pandemic restrictions, Universitat Jaume I has increased its investment on developing training courses for lectures to better use Moodle environment, and Google applications, such as Google Drive, Google Meet, and other applications such as Autocrat.

This training process should enforce new skills in lecturers to adapt their lessons and contents to the elearning environment, and also their evaluation system, giving increasing importance to team-based projects and continuous evaluation assignments. According to Sun et al. (2020) lecturers should be conscious that they cannot simply transfer online the information that was usually taught in the traditional way.

\section{Resources for Developing Classes During COVID-19 Pandemic}

Specifically, the lecturers of the 'Introduction to Firms Information Systems' subject created a supportive group operating through the social network Telegram, which help lecturers with the schedule and organization of new classes, as well as with the diffusion of the latest policies adopted by the Universitat Jaume I and the government.

As we explain below, most of the contents were introduced and administered through Moodle. Moodle is considered an example of a web-based learning environment designed to enhance collaboration between students, lecturers and administrations. This platform eliminates barriers of space and time, and offers the students access to a wide range of contents, videos, links, activities, tasks and questionnaires; these resources were all introduced by the lecturers of 'Introduction to Firms Information Systems' subject to support the theoretical classes. Moodle also facilitates collaboration among students and lectures through forums and private messaging, lecturers to share additional information in an asynchronous way, as well as students to state their difficulties and receive feedback (Forés et al., 2019). Therefore, Moodle platforms are considered easy to use and they are known to have a positive impact on students' learning results (Coman et al., 2020).

The lecturers also introduced each lesson in streaming, using Google Meet, which allows video and audio, and written communication through a chat where users can send messages and receive responses in real-time (Dhawan, 2020). The lectures also prepared some additional videos to reinforce the classes. 
Platforms such as Google Meet, Microsoft teams and Zoom platforms were considered crucial applications to reach students and reduce their feelings of isolation, and teach them at their home during the quarantine (Dhawan, 2020). These platforms were also useful for supporting students in the development of their practical exercises in the subject consisting of a database team-based project and the individual resolution of cases through Microsoft Excel, through tutorial classes. These tutorial classes were essential for teachers to involve students in the learning process through the rapid provision of feedback on the tasks solved by students and giving them continuous support.

All in all, both Moodle and Google Meet were useful to motivate students to interact with their peers and lecturers, discuss and exchange points of view and ideas. In addition, both methodologies allowed lecturers to provide students with personal attention, so that students could be easily adapted to this learning environment (Dhawan, 2020).

We also introduced interactive resources such as Kahoot to reinforce the student's preparation for the final theoretical exam, based on a questionnaire with both multiple choice and open development questions. Lecturers also devoted a lot of time in making effective strategies for giving online instructions related to both the methodology and evaluation system of the subject.

\section{The Evaluation Adaptation to COVID-19 Context}

As previously mentioned, lecturers used Moodle questionnaires for the evaluation of the theoretical part. These questionnaires randomly took a battery of previous questions introduced by lecturers, and organized by topics and lessons. In this vein, the theoretical exam questionnaire was different for each student. The questionnaire did not allow students to check the answered questions and had a time limit. Finally, the questionnaire included two open questions for students to develop, also with a limit of time and without any option to review the sent answer. Lecturers attended the students' questions during the exam through Google Meet.

The lecturers used Autocrat complement for Google Drive to deliver the Excel exam, which was adapted for each student. Autocrat allows lecturers to generate and share Google spreadsheets in Drive, reusing and customizing document templates across multiple merge jobs in an efficient way.

Finally, the students had to upload to different tasks created in Moodle their individual Excel exams and Access projects, shared and performed in groups at home.

\section{STUDENTS' ASSESSMENT OF THE LEARNING PROCESS}

We conducted an online questionnaire to examine students' perceptions regarding their attitude and difficulties found towards exclusively online learning and the ability of the lecturers to provide knowledge in the context of exclusively online learning.

Specifically, in this study the following research questions were addressed through a non-standardized questionnaire:

1. Ease and advantages of online classes: a) ease to follow and understand the subject online; $b$ ) advantages of online teaching (dichotomous and open questions); and c) preference for an online learning environment.

2. Effort and difficulties of online classes: a) effort to follow the online classes; and b) difficulty to follow the online classes (dichotomous and open questions).

3. Lecturer's effort and adaptation: a) lecturer's support and feedback; b) lecturer's effort to adapt the teaching of the subject (dichotomous and open questions); and c) suggestions for improvement (open question).

The population for the study was selected in a non-probabilistic way and consisted of 28 students. Data was collected online. The questionnaire was available for the students in a link on the Moodle platform. 


\section{RESULTS}

This section presents the results of the empirical study carried out and it is divided in three subsections according to the research questions outlined above.

\section{Ease and Advantages of Online Classes}

The first subsection illustrates the results of the survey on students' perceptions of the advantages of online education and their preference for it over traditional face-to-face education.

a) Ease to follow and understand the subject online

This question is intended to inquire if the students found easier to follow and understand the subject in an online learning environment. According to the results of the survey, $82.14 \%$ of the respondents answered that they did find it easier to follow and understand the course content through the use of digital media (see Figure 1).

b) Advantages of teaching online

In this second question the students were asked whether they thought that e-learning mode of the subject had any advantages for them and, if so, what kind of advantages. In this vein, $64.28 \%$ of the students surveyed indicated that teaching the subject through digital media did have advantages (see Figure 1). As reported in Figure 2, the main advantages pointed out by the students of online learning were related to a better monitoring of the contents of the subject, more time to carry out the exercises and the learning flexibility.

c) Preference for an online learning environment

One of the main goals of this study is to know whether the students preferred the subject to be taught online or if, on the contrary, they preferred the traditional face-to-face method. This question seeks to gauge this preference quantitatively. In this sense, a total of $28.57 \%$ of the students pointed out that they preferred online learning of the subject. On the contrary, a total of $60.71 \%$ of the respondents indicated that they still preferred the traditional face-to-face learning model. Finally, $10.71 \%$ of the students did not indicate a clear preference for any of the teaching modes (see Figure 1).

FIGURE 1

EASE AND ADVANTAGES OF ONLINE LEARNING

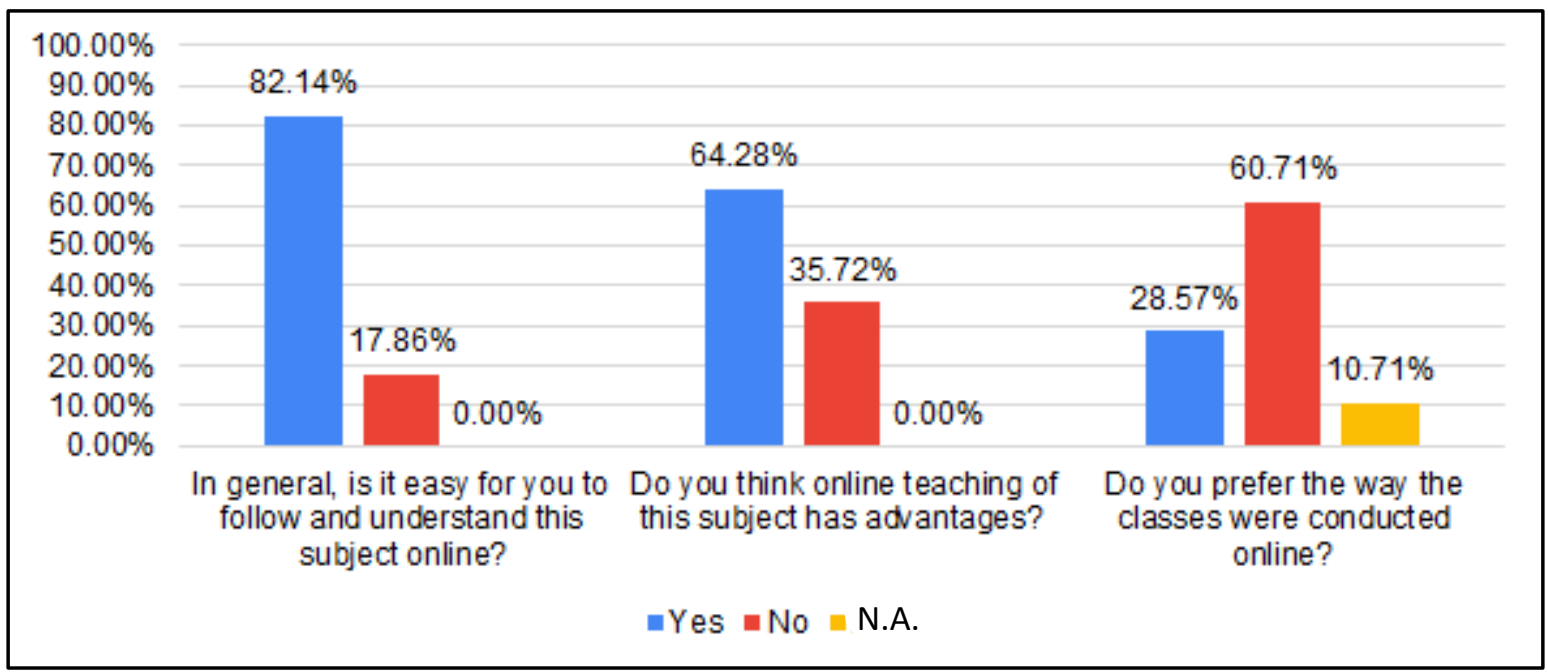




\section{FIGURE 2 \\ DETAILED ADVANTAGES OF ONLINE LEARNING}

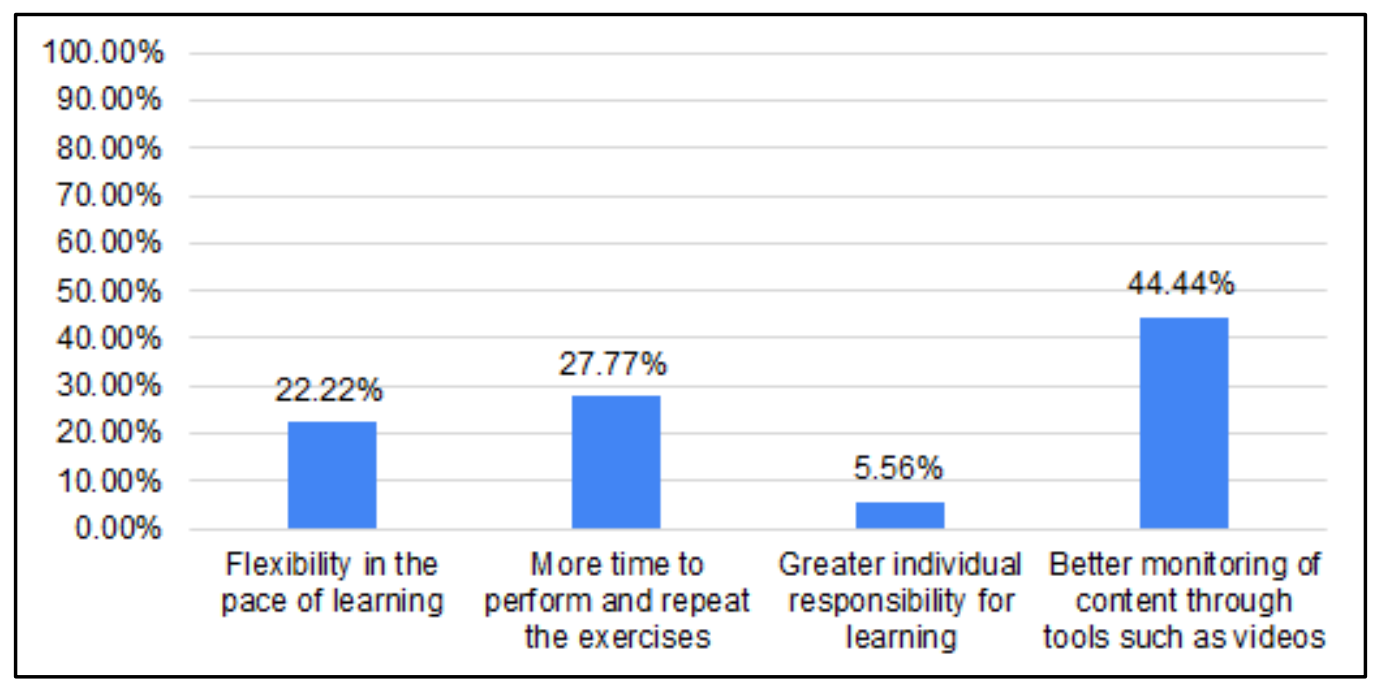

\section{Effort and Difficulties of Online Classes}

This second sub-section collects the results of the survey regarding the efforts made by students to follow the subject and the difficulties they have encountered.

a) Effort to follow the online classes

In this question the goal is to know whether the students have made a greater effort to follow online classes compared to the traditional face-to-face model. This time, the results are more balanced, as $53.57 \%$ of respondents pointed out that following up online classes required a greater effort compared to $46.42 \%$ who declared they didn't make additional efforts that they would have done in a face-to-face class (see Figure 3).

b) Difficulty to follow the online classes

Regarding the difficulties found by students in following-up the subject through online learning, the results confirm that $46.42 \%$ of the students surveyed encountered difficulties in following-up the subject by digital media (see Figure 3). Concerning the main difficulties encountered, these were related to the follow-up of the practical exercises of the subject (Microsoft Excel and Microsoft Access), as reported by $53.84 \%$ of the students. Other difficulties pointed out by the respondents were related to their family situation, technical problems (e.g., network connection failures), and occasional doubts and concerns about the development of the course (see Figure 4). All of them obtained the same percentage of representativeness $(15.38 \%)$. 
FIGURE 3

STUDENT'S EFFORT AND DIFFICULTIES TO FOLLOW ONLINE CLASSES

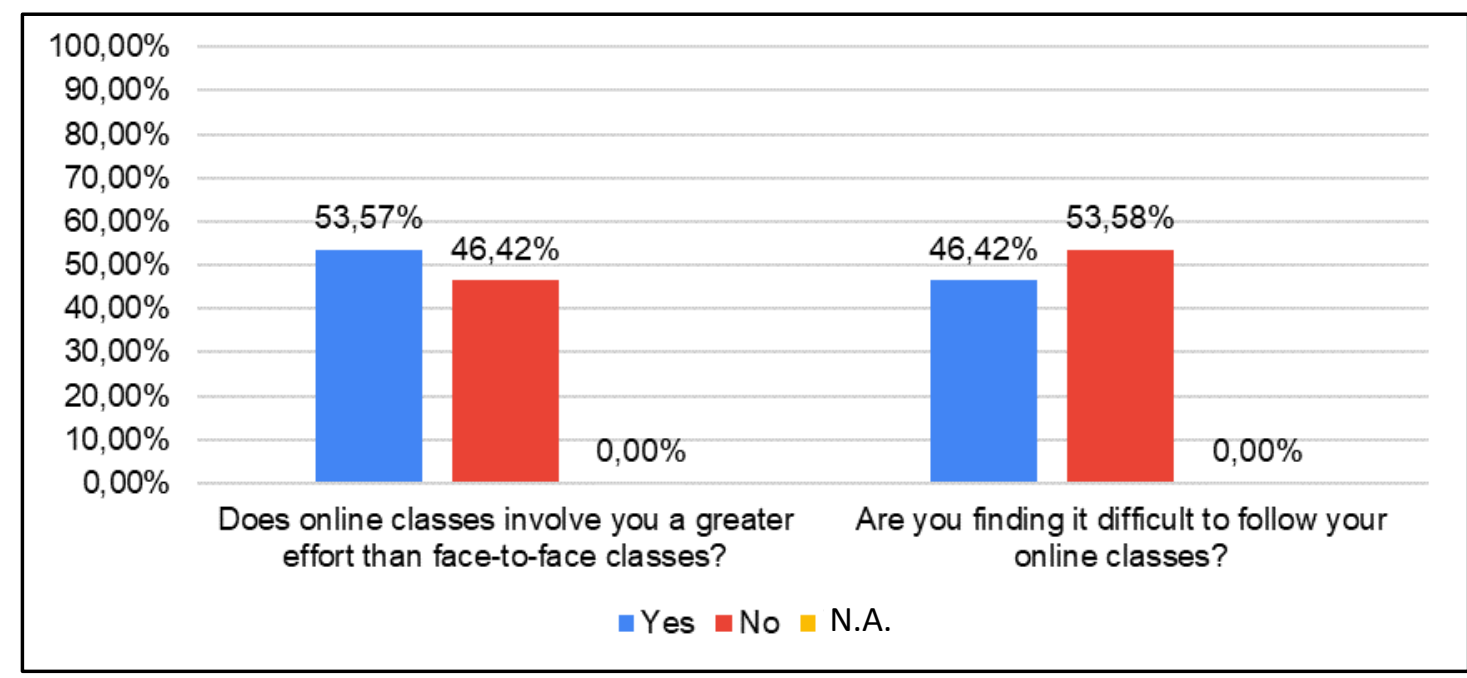

FIGURE 4

DETAILED DIFFICULTIES FOUND BY STUDENTS TO FOLLOW ONLINE CLASSES

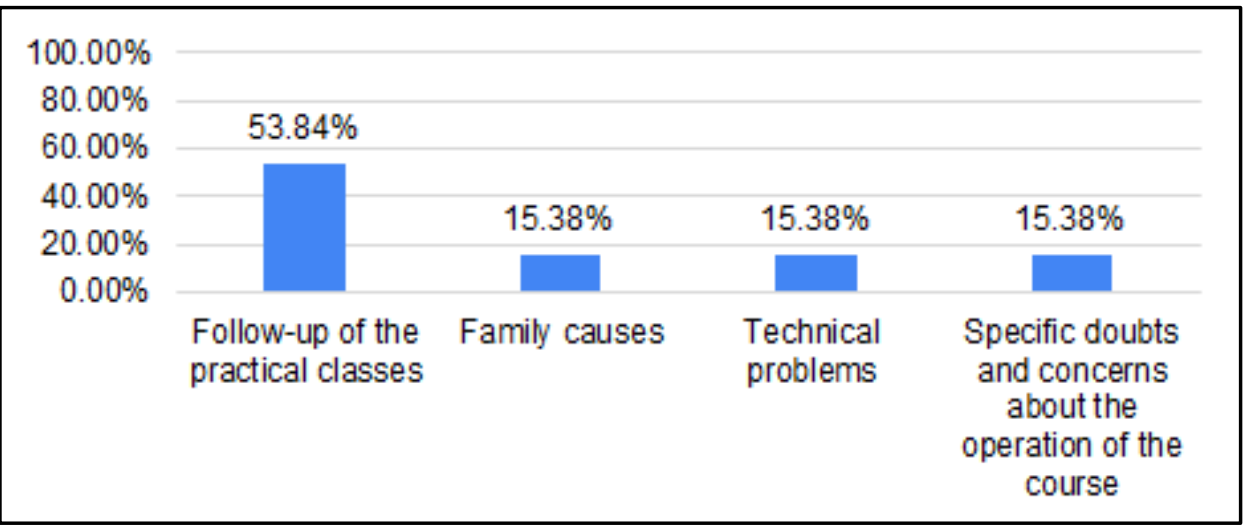

\section{Lecturer's Effort and Adaptation}

This last sub-section illustrates the results of the survey on student perceptions about the support and the efforts made by the lecturers to adapt the course content to an online teaching environment. It also includes the suggestions of the students for the improvement of the subject.

a) Lecturer's support and feedback

This question requires students to indicate whether their teacher has addressed their concerns adequately. The response is highly satisfactory, as $100 \%$ of the students surveyed have stated that the lecture addresses their concerns correctly (see Figure 5).

b) Lecturer's effort to adapt the teaching of the subject

This question aims to know if students considered that the lecturers' effort to adapt the teaching to the new situation were appropriate. In this respect, for $89.28 \%$ of respondents the efforts made to adapt the subject to online learning were adequate, whereas for $3.57 \%$ of the students were not enough. A succinct $7.14 \%$ of the respondents preferred not to answer the question (see Figure 5). Regarding the reasons that justify this positive assessment, students pointed out, among other reasons, the good work done by lecturers to facilitate learning or the use of helpful digital resources (e.g., videos) to better understand the content of the subject (see Figure 6). 
c) Suggestions for improvement

With the aim of taking into account the students' opinion, the last question requested them to suggest improvements for the online development of the subject in an open way. The proposals made by the students were very varied, from requesting the development of classes in a synchronous way, to changes in the evaluation model of the subject or the incorporation of new videos also on the theoretical part of the subject, among other responses (see Figure 7).

\section{FIGURE 5 \\ LECTURERS' EFFORT AND ADAPTATION}

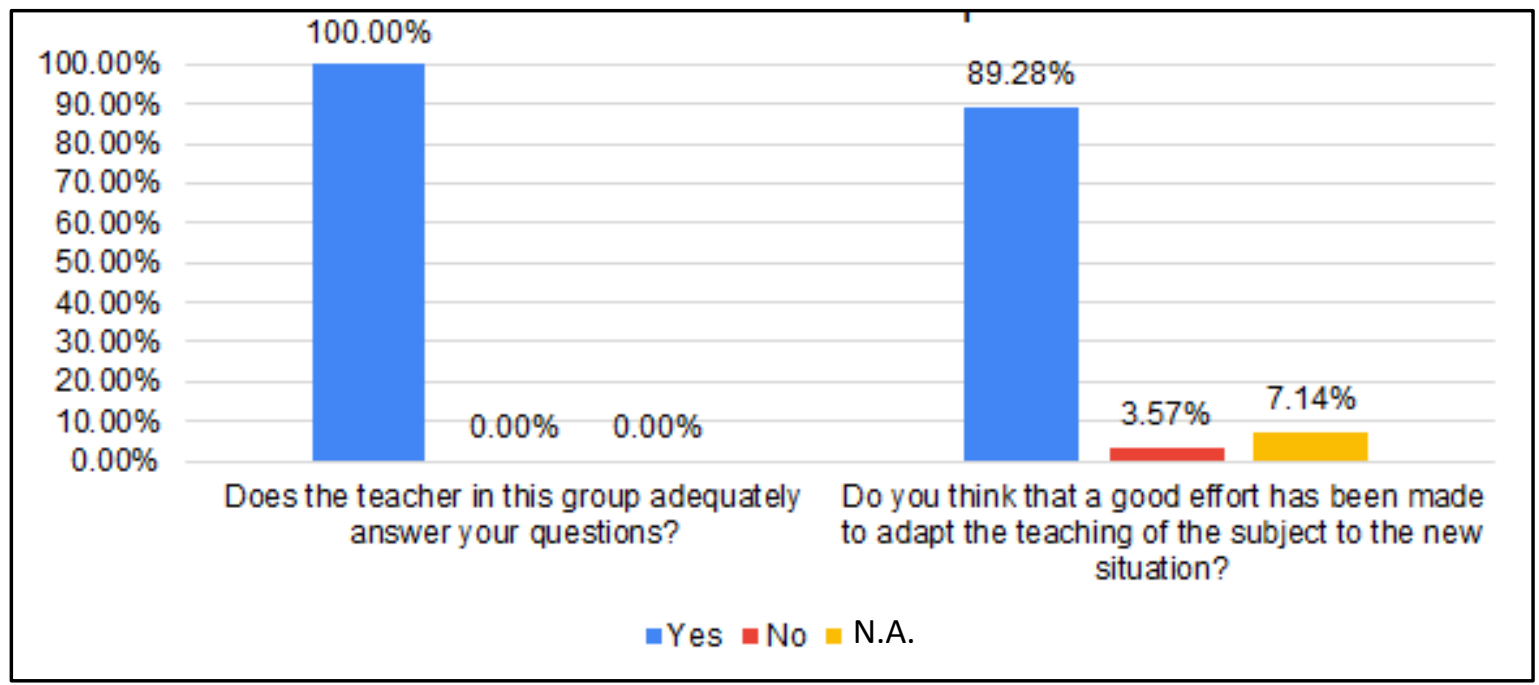

FIGURE 6

EXAMPLES OF LECTURERS' ACTIVITIES AND RESOURCES INTRODUCED TO ADAPT THE LEARNING PROCESS

\begin{tabular}{|c|c|c|c|c|c|}
\hline \multicolumn{6}{|l|}{$100.00 \%$} \\
\hline \multicolumn{6}{|l|}{$90.00 \%$} \\
\hline \multicolumn{6}{|l|}{$80.00 \%$} \\
\hline \multicolumn{6}{|l|}{$70.00 \%$} \\
\hline $60.00 \%$ & \multicolumn{5}{|l|}{$48.00 \%$} \\
\hline $\begin{array}{l}50.00 \% \\
40.00 \%\end{array}$ & & & & & \\
\hline $30.00 \%$ & & $20.00 \%$ & & & $20.00 \%$ \\
\hline $\begin{array}{l}20.00 \% \\
1000 \%\end{array}$ & & & $8.00 \%$ & $4.00 \%$ & \\
\hline \multirow{2}{*}{$\begin{array}{r}10.00 \% \\
0.00 \%\end{array}$} & & & 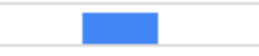 & . & \\
\hline & $\begin{array}{l}\text { The teachers } \\
\text { have done a } \\
\text { great job in } \\
\text { facilitating } \\
\text { learning }\end{array}$ & $\begin{array}{c}\text { Digital resources } \\
\text { (such as videos) } \\
\text { have been very } \\
\text { useful }\end{array}$ & $\begin{array}{l}\text { The content is } \\
\text { maintained as in r } \\
\text { the face-to-face } \\
\text { format }\end{array}$ & $\begin{array}{l}\text { The course is } \\
\text { related to digital } \\
\text { technologies }\end{array}$ & $\begin{array}{c}\text { No reasons } \\
\text { specified }\end{array}$ \\
\hline
\end{tabular}




\section{FIGURE 7 \\ STUDENTS' SUGGESTIONS FOR IMPROVING THE LEARNING PROCESS}

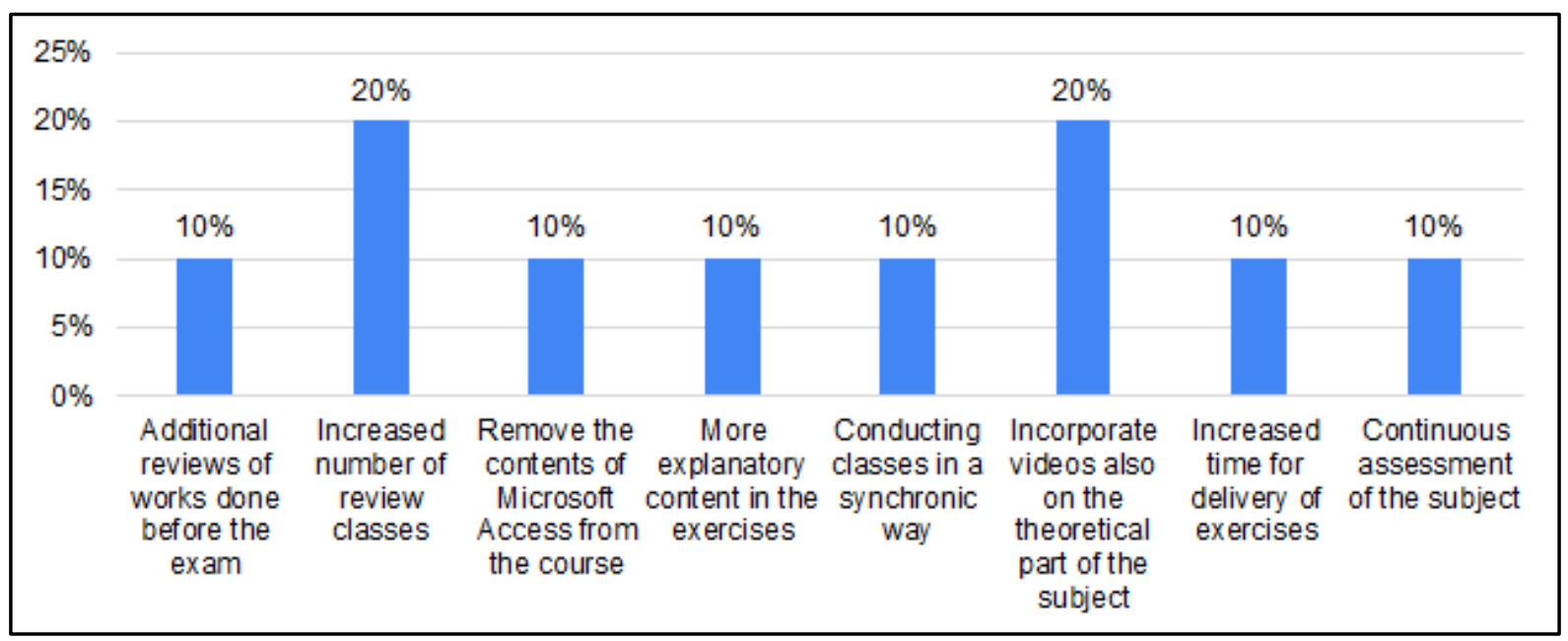

\section{CONCLUSIONS}

In the context of the crisis created by the Coronavirus pandemic we assisted to a major change in the higher education system: the transition to a student-centered e-learning process in a relatively short period of time. The challenge to educational institutions is not only finding new technology but also helping students and academic staff who are seeking guidance for digital literacy. Another lesson learned from the pandemic is that students should acquire certain transversal skills such as problem-solving, critical thinking, and adaptability to drastic changes in the environment (Dhawan, 2020).

Universitat Jaume I have developed a series of actions that have enhanced the successful adaptation to online learning and teaching, such as the development of training sessions for teachers, and the investment in technologies and platforms, and in digital devices to help students with their special needs. However, it is also of utmost importance that lectures offer support to students' needs and concerns in order to increase their motivation and involvement in e-learning processes.

In order to know the student's adaptation and attitudes to this new learning context, the lecturers of the subject Introduction to Firms Information Systems, taught in the degrees of Business Administration, Finance and Accounting, and Economics at the Universitat Jaume I, conducted an empirical study.

The results of the study on a sample of 28 students has served to draw a number of interesting conclusions. Firstly, it highlights that, despite the fact that students found it easy to follow and understand the subject online and even consider that this learning method has some advantages, a majority of them $(60.71 \%)$ still have a predilection for the development of the classes in the traditional face-to-face model.

Secondly, the empirical results confirm that the students consider that the follow-up of the online classes requires additional efforts to those they would make if the classes were held in the university classrooms (53.57\%). In this sense, it is important to highlight that the main difficulties pointed out by students are related to the monitoring of practical exercises (Microsoft Excel and Access), as could be expected for the practicality and interactivity of this part of the subject.

Thirdly, as regards the effort made by the lecturers to adapt the contents of the subject and to provide support to the students, it should be noted that the assessment of the students has been fully satisfactory $(100 \%)$.

These results confirm previous studies (Coman et al., 2020) showing that students have positive attitudes towards online learning, confirming previous studies, even though they sometimes encountered technical issues. 
Lastly, the empirical study carried out has provided interesting proposals from the students for the improvement of the subject. Among these suggestions, it is worth mentioning their request for the incorporation of more digital didactic material or for a greater number of review classes before the exam.

\section{ACKNOWLEDGEMENT}

This research has been funded by Universitat Jaume I by a project of the Unitat de Suport Educatiu: "Educant per a la sostenibilitat en temps de COVID: noves metodologies i ferramentes per a la docència a l'àmbit de l'administració d'empreses" (Ref. 3979/21). It is also part of a research project of the Universitat Jaume I (Ref. UJI-A2019-20). The author José María Fernández Yáñez has been supported by the predoctoral aid with reference PD-UJI/2019/13.

\section{REFERENCES}

Adnan, M., \& Anwar, K. (2020). Online Learning amid the COVID-19 Pandemic: Students' Perspectives. Journal of Pedagogical Sociology and Psychology, 2(1), 45-51.

Ali, W. (2020). Online and remote learning in higher education institutes: A necessity in light of COVID19 pandemic. Higher Education Studies, 10(3), 16-25.

Coman, C., Țîru, L.G., Meseșan-Schmitz, L., Stanciu, C., \& Bularca, M.C. (2020). Online Teaching and Learning in Higher Education during the Coronavirus Pandemic: Students' Perspective. Sustainability, 12(24), 10367.

Dhawan, S. (2020). Online learning: A panacea in the time of COVID-19 crisis. Journal of Educational Technology Systems, 49(1), 5-22.

Forés, B., Ferrer-Gilabert, S., \& Fernández-Yáñez, J.M. (2019). Hacia un aprendizaje activo. La introducción de TIC en la docencia en Administración de Empresas. In B. Forés \& M.L. LaraOrtiz (Eds.), Experiencias de innovación docente. València: Tirant Lo Blanch.

Huang, R., Tlili, A., Chang, T.W., Zhang, X., Nascimbeni, F., \& Burgos, D. (2020). Disrupted classes, undisrupted learning during COVID-19 outbreak in China: Application of open educational practices and resources. Smart Learning Environments, 7(1), 1-15.

Organisation for Economic Cooperation and Development [OECD]. (2020). Education Responses to COVID-19: Embracing Digital Learning and Online Collaboration, 2020. Retrieved August 14, 2020 from http://www.oecd.org/coronavirus/policy-responses/education-responses-to-covid-19embracing-digital-learning-and-online-collaboration-d75eb0e8/

Singh, V., \& Thurman, A. (2019). How many ways can we define online learning? A systematic literature review of definitions of online learning (1988-2018). American Journal of Distance Education, 33(4), 289-306.

Sun, L., Tang, Y., \& Zuo, W. (2020). Coronavirus pushes education online. Nature Materials, 19(6), 687-687.

Suresh, M., Vishnu Priya, V., \& Gayathri, R. (2018). Effect of e-learning on academic performance of undergraduate students. Drug Invention Today, 10(9), 1797-1800. 